\title{
Faktor Risiko Manual Handling dengan Keluhan Nyeri Punggung Bawah Pembuat Batu Bata
}

\author{
Heru Subaris Kasjono ${ }^{1}$, Yamtana ${ }^{2}$, Dian Intan Pandini ${ }^{3}$ \\ 1,2,3 Jurusan Kesehatan Lingkungan, Politeknik Kesehatan Kemenkes Yogyakarta \\ Email: dian.intann14@gmail.com
}

\begin{abstract}
Risk Factors Manual Handling with Complaints of Lower Back Pain on Brick Makers. During done manual work handling for objects work hard, it will cause risk of injury or cause musculoskeletal systems. Risk assessment manual work handling with the methods indicators key-Leitmerkmal Method (LMM) intended to know the relationship between time, burden, attitudes of the body, and working conditions manual handling with complaints of the lower back pain at all stages making bricks perceived maker bricks. The kind of research used is surveyed such data is cross sectional. The data taken by lower back pain questionnaire assisted examination physically by nurses and checklist Key-LMM. Analysis relations use the spearman. The results of research acquired at variable time manual handling based frequency raised or operation the transfer of on stage excavation raw materials, the formation and drying bricks there are relations with complaints of low back pain with $p$ value each are $0,039,0,047,0,038$ while on the variables of working conditions manual handling in stage excavation raw materials obtained $\mathrm{p}$ value of 0,028 with so it can be said there was a correlation between working conditions manual handling with complaints low back pain. A variable load manual handling and attitudes of the body manual handling do not relate in significant to lower back pain all stages making bricks. Conclusion researchers that the variable time manual handling relate in significant with complaints lower back pain in stage excavation raw materials, the formation and drying bricks, while the phase processing raw materials that there was no correlation, in a variable load manual handling and attitudes of the body manual handling all these stage there was no correlation with complaints lower back pain, while variable working conditions manual handling only in stage excavation the raw materials there are relations with complaints lower back pain in the third stage other there was no correlation.
\end{abstract}

Keywords: Manual handling, Low back pain, Bricks

\begin{abstract}
Abstrak: Faktor Risiko Manual Handling dengan Keluhan Nyeri Punggung Bawah pada Pembuat Batu Bata. Pekerjaan manual handling untuk obyek kerja yang berat, dapat menyebabkan risiko cedera atau menyebabkan keluhan sistim musculosketal. Penilaian risiko pekerjaan manual handling dengan metode Indikator Kunci-Leitmerk MalMethode (LMM) dimaksudkan untuk mengetahui hubungan antara waktu, beban, sikap tubuh,dan kondisi kerja manual handling dengan keluhan nyeri punggung bawah pada semua tahapan pembuatan batu-bata yang dirasakan pembuat batu-bata. Jenis penelitian yang digunakan adalah survei, dengan pengambilan data secara cross sectional. Pengumpulan data dengan membagikan kuesioner nyeri punggung bawah dibantu pemeriksaan fisik oleh perawat, dan checklist Kunci-LMM. Analisis hubungan antar variabel menggunakan Spearman. Hasil penelitian yang didapat pada variabel waktu manual handling didasarkan frekuensi mengangkat atau operasi pemindahan pada tahapan penggalian bahan mentah, pembentukan dan pengeringan batu-bata terdapat hubungan dengan keluhan nyeri punggung bawah dengan nilai p value masing yaitu $0,039,0,047,0,038$ sedangkan pada variabel kondisi kerja manual handling di tahapan penggalian bahan mentah didapat nilai $\mathrm{p}$ value sebesar 0,028 dengan begitu dapat dikatakan ada hubungan anatar kondisi kerja manual handling dengan keluhan nyeri punggung bawah. Variabel beban kerja manual handling dan sikap tubuh manual handling tidak berhubungan secara signifikan terhadap nyeri punggung bawah di semua tahapan pembuatan batu-bata. Kesimpulan peneliti bahwa variabel waktu manual handling berhubungan secara signifikan dengan keluhan nyeri punggung bawah di tahapan penggalian bahan mentah, pembentukan dan pengeringan batu-bata, sedangkan dalam tahapan pengolahan bahan mentah tidak terdapat hubungan, pada variabel beban manual handling dan sikap tubuh manual handling di semua tahapan tidak terdapat hubungan dengan keluhan nyeri punggung bawah, sedangkan variabel kondisi kerja manual handling hanya di tahapan penggalian bahan mentah yang terdapat hubungan dengan keluhan nyeri punggung bawah di ketiga tahapan lain tidak terdapat hubungan.
\end{abstract}

Kata kunci: Manual handling, Nyeri punggung bawah, Batu bata 
Dewasa ini begitu banyak pekerjaan yang dilakukan dengan menggunakan mesin, mulai dari mesin yang sangat sederhana sampai dengan penggunaan mesin dengan berbasis teknologi tinggi. Disisi lain, ternyata diberbagai industri juga masih banyak pekerjaan yang harus dilakukan secara manual yang memerlukan tuntutan dan tekanan secara fisik yang benar (Simanjuntak, 2011). Manual handling didefinisikan sebagai suatu pekerjaan yang berkaitan dengan mengangkat, menurunkan, mendorong, menarik, menahan, mambawa atau memindahkan beban dengan satu tangan atau kedua tangan dan atau dengan pengerahan seluruh badan (Tarwaka, 2015).

Lebih seperempat dari total kecelakaan kerja terjadi berkaitan dengan pekerjaan manual handling. Selama dilakukan pekerjaan manual handling untuk obyek kerja yang berat, maka akan dapat menyebabkan risiko cedera atau menyebabkan gangguan sistem muskuloskeletal, khususnya pada pinggang. Untuk menilai risiko tersebut, di Jerman telah dikembangkan "Metode Indikator Kunci-LMM". Metode ini memperhitungkan empat faktor atau parameter stres fisik yang terjadi selama pekerjaan manual handling, yaitu: waktu (time), beban atau massa (load/ mass), sikap tubuh (body posture), kondisi selama kerja (condition of performing work) (Tarwaka, 2015).

Nyeri Punggung Bawah (NPB) adalah nyeri yang dirasakan pada daerah punggung bawah, dapat berupa nyeri lokal maupun nyeri radikuler atau keduanya. Nyeri ini terasa diantara sudut iga terbawah sampai lipat bokong bawah yaitu didaerah lumbal atau lumbosakral dan sering disertai dengan penjalaran nyeri kearah tungkai dan kaki. NPB merupakan efek umum dari Manual Material Handling (MMH). Menurut Luopajarvi (1990) dalam (Astuti, 2007) beban kerja yang berat, postur kerja yang salah dan perulangan gerakan yang tinggi, serta adanya getaran terhadap keseluruhan tubuh merupakan keadaan yang memperburuk penyakit NPB. Faktor-faktor risiko lain yang turut mempengaruhi timbulnya NPB antara lain umur, jenis kelamin, indeks massa tubuh (IMT), jenis pekerjaan, dan masa kerja (Samara, 2005).

Berdasarkan pengamatan peneliti aktifitas pekerja industri batu-bata yang dilakukan secara manual dapat menjadi faktor risiko terjadinya NPB. Hal ini dikarenakan beberapa tahapan proses pekerjaan terdiri dari mencangkul tanah, memasukkan tanah ke dalam gerobak sorong, mencetak batu bata dengan alat cetak, mengangkat batu bata dengan gerobak sorong serta menyusun batu-bata yang akan dibakar serta mengangkat kedalam mobil pengangkut.

Berdasarkan observasi tanggal 26 Januari 2017 di home industry batu-bata di Dusun Asri Desa Srimulyo Gondang Sragen, dengan jumlah responden 10 orang menggunakan kuesioner gejala nyeri punggung bawah, $30 \%$ pekerja mengeluh nyeri punggung bawah. Kebanyakan responden merasakan panas, kaku, nyeri tertusuktusuk pada bagian punggung bawah.

\section{METODE}

Penelitian ini menggunakan rancangan Cross Sectional. Data diukur atau dikumpulkan dalam waktu yang bersamaan dengan metode pengisian kuesioner dan check list.

Penelitian dilaksanakan bulan Januari-Juni 2017 pada 39 pembuat batu-bata di Dusun Asri, Srimulyo, Gondang, Sragen yang diambil secara acak sederhana (Simple Random Sampling).

Variabel bebas yang diteliti adalah waktu manual handling, beban manual handling, sikap tubuh manual handling dan kondisi kerja manual handling. Adapun sebagai variabel terikat yaitu nyeri punggung bawah.

Alat dan bahan penelitian: Alat tulis, Kuesioner, dan Check List. Setiap responden diberikan kuesioner nyeri punggung bawah, selanjutnya responden menjawab setiap pertanyaan yang terdapat di dalam kuesioner dengan didampingi oleh peneliti, namun apabila terdapat responden yang tidak dapat mengisi maka akan dibantu peneliti. Untuk mengetahui waktu manual handling, beban manual handling, sikap tubuh manual handling dan kondisi kerja manual handling dilakukan dengan cara pengamatan menggunakan Check List.

\section{HASIL}

\section{Karakteristik Responden}

Tabel 1. Berdasarkan Jenis Kelamin

\begin{tabular}{lrr}
\hline \multicolumn{1}{c}{ Jenis Kelamin } & Jumlah & \multicolumn{1}{c}{} \\
\hline Laki-laki & 19 & 48,7 \\
Perempuan & 20 & 51,3 \\
\hline Jumlah & 39 & 100 \\
\hline
\end{tabular}

Berdasarkan Tabel 1, diketahui responden perempuan lebih banyak dari responden laki-laki. Perempuan 51,3\% dan laki-laki 48,7\%. 
Tabel 2. Berdasarkan Usia

\begin{tabular}{lrr}
\hline \multicolumn{1}{c}{ Usia (tahun) } & Jumlah & \% \\
\hline Dewasa $(21-40)$ & 15 & 38,4 \\
Tua $(41->60)$ & 24 & 61,6 \\
\hline Jumlah & 39 & 100 \\
\hline
\end{tabular}

Berdasarkan Tabel 2, diketahui responden yang berusia tua $(41->60)$ memiliki proporsi yang terbanyak $(61,6 \%)$.
Tabel 3. Berdasarkan Masa Kerja

\begin{tabular}{ccc}
\hline Masa Kerja (tahun) & Jumlah & \% \\
\hline$<15$ & 15 & 38,4 \\
$\geq 15$ & 24 & 61,6 \\
\hline Jumlah & 39 & 100 \\
\hline
\end{tabular}

Berdasarkan Tabel 3, dapat dijelaskan responden dengan masa kerja $\geq 15$ tahun memiliki proporsi terbanyak $(61,6 \%)$.

\section{Waktu Manual Handling Pembuat Batu-Bata Pertahapan Pembuatan}

Tabel 4. Distribusi Frekuensi Waktu Manual Handling Berdasarkan Frekuensi (Jumlah/1 hari kerja) Mengangkat atau Operasi Pemindahan ( $<5$ detik) Pembuat Batu-Bata pada Tahapan Penggalian dan Pengolahan Bahan Mentah

\begin{tabular}{|c|c|c|c|c|c|c|c|c|c|}
\hline \multicolumn{2}{|c|}{$\begin{array}{l}\text { Mengangkat atau operasi } \\
\text { pemindahan }(<5 \text { detik })\end{array}$} & \multicolumn{2}{|c|}{$\begin{array}{l}\text { Pembentukan } \\
\text { Batu-Bata }\end{array}$} & \multirow{2}{*}{$\begin{array}{l}\text { Median } \\
\& \\
\text { Modus }\end{array}$} & \multirow{2}{*}{ Mean } & \multicolumn{2}{|c|}{$\begin{array}{l}\text { Pengeringan } \\
\text { Batu-Bata }\end{array}$} & \multirow{2}{*}{$\begin{array}{l}\text { Median } \\
\& \\
\text { Modus }\end{array}$} & \multirow[t]{2}{*}{ Mean } \\
\hline Kategori & $\begin{array}{c}\text { Frekuensi (Jumlah/ } \\
1 \text { hari kerja) }\end{array}$ & $\mathrm{F}$ & $\%$ & & & $\mathrm{~F}$ & $\%$ & & \\
\hline 1 & $(<10)$ & - & - & & & - & - & & \\
\hline 2 & $(10-<40)$ & 6 & 15,4 & & & - & - & & \\
\hline 4 & $(40-<200)$ & 27 & 69,2 & & & 10 & 25,6 & & \\
\hline 6 & $(200-<500)$ & 3 & 7,7 & 4 & 142 & 28 & 71,8 & 6 & 374 \\
\hline 8 & $(500-<1000)$ & 2 & 5,1 & & & 1 & 2,6 & & \\
\hline \multirow[t]{2}{*}{10} & $(\geq 1000)$ & 1 & 2,6 & & & - & - & & \\
\hline & Jumlah & 39 & 100 & & & 39 & 100 & & \\
\hline
\end{tabular}

Berdasarkan Tabel 4, diketahui dari 39 responden, untuk kategori waktu manual handling mengangkat atau operasi pemindahan pada tahapan penggalian bahan mentah yang paling banyak dengan frekuensi $200-<500 / 1$ hari kerja sebanyak 21 responden $(53,8 \%)$. Untuk tahapan pengolahan bahan mentah yang paling banyak dengan frekuensi 40- <200/1 hari kerja sebanyak 18 responden $(46,1 \%)$. Nilai median dari kategori waktu manual handling mengangkat atau operasi pemindahan pada tahapan penggalian bahan mentah yaitu 6 dan nilai modus yaitu 6 atau frekuensi 200- <500/1 hari kerja, sedangkan rata-rata atau nilai mean waktu manual handling mengangkat atau operasi pemindahan pada tahapan penggalian bahan mentah adalah 275/1 hari kerja. Pada tahapan pengolahan bahan mentah nilai median yaitu 6 atau frekuensi 200- $<500 / 1$ hari kerja dan nilai modus yaitu 4 atau rekuensi 40- $<200 / 1$ hari kerja, sedangkan rata-rata atau nilai mean waktu manual handling mengangkat atau operasi pemindahan pada tahapan pengolahan bahan mentah adalah 325/ 1 hari kerja.

Tabel 5. Distribusi Frekuensi Waktu Manual Handling Berdasarkan Frekuensi (Jumlah/ 1 hari kerja) Mengangkat atau Operasi Pemindahan ( $<5$ detik) Pembuat Batu-Bata pada Tahapan Pembentukan dan Pengeringan

\begin{tabular}{|c|c|c|c|c|c|c|c|c|c|}
\hline \multicolumn{2}{|c|}{$\begin{array}{l}\text { Mengangkat atau operasi } \\
\text { pemindahan }(<5 \text { detik })\end{array}$} & \multicolumn{2}{|c|}{$\begin{array}{c}\text { Penggalian } \\
\text { Bahan Mentah }\end{array}$} & \multirow{2}{*}{$\begin{array}{l}\text { Median \& } \\
\text { Modus }\end{array}$} & \multirow{2}{*}{ Mean } & \multicolumn{2}{|c|}{$\begin{array}{c}\text { Pengolahan } \\
\text { Bahan Mentah }\end{array}$} & \multirow{2}{*}{$\begin{array}{l}\text { Median \& } \\
\text { Modus }\end{array}$} & \multirow{2}{*}{ Mean } \\
\hline Kategori & $\begin{array}{l}\text { Frekuensi (Jumlah/ } \\
1 \text { hari kerja) }\end{array}$ & $\mathrm{F}$ & $\%$ & & & $\mathrm{~F}$ & $\%$ & & \\
\hline 1 & $(<10)$ & - & - & & & - & - & & \\
\hline 2 & $(10-<40)$ & 5 & 12,9 & & & 1 & 2,6 & & \\
\hline 4 & $(40-<200)$ & 9 & 23 & & & 18 & 46,1 & Mod $=4$ & \\
\hline 6 & $(200-<500)$ & 21 & 53,8 & 6 & 275 & 15 & 38,5 & Med $=6$ & 325 \\
\hline 8 & $(500-<1000)$ & 4 & 10,3 & & & 5 & 12,8 & & \\
\hline \multirow[t]{2}{*}{10} & $(\geq 1000)$ & - & - & & & - & - & & \\
\hline & Jumlah & 39 & 100 & & & 39 & 100 & & \\
\hline
\end{tabular}


Berdasarkan Tabel 5, diketahui dari 39 responden, kategori waktu manual handling pada tahapan pembentukan batu-bata yang paling banyak adalah dengan frekuensi 40- $<200 / 1$ hari kerja sebanyak 27 responden $(69,2 \%)$, serta pada tahapan pengeringan batu-bata yang paling banyak adalah dengan frekuensi 200- $<500 / 1$ hari kerja sebanyak 28 responden $(71,8 \%)$. Nilai median dan modus dari kategori waktu manual handling pada tahapan pembentukan batu-bata yaitu 4 atau frekuensi 40- $<200 / 1$ hari kerja, sedangkan rata-rata atau nilai mean waktu manual handling pada tahapan pembentukan batu-bata adalah 142/ 1 hari kerja. Pada tahapan pengeringan batu-bata nilai median dan modusnya yaitu 6 atau frekuensi 200- <500/1 hari kerja, sedangkan rata-rata atau nilai mean waktu manual handling pada tahapan pengeringan batubata adalah 374/ 1 hari kerja.

\section{Beban Manual Handling Untuk Laki-Laki dan Wanita Pembuat Batu-Bata Pertahapan}

\section{a. Untuk Laki-laki}

Tabel 6. Distribusi Frekuensi Beban Manual Handling Berdasarkan Beban Efektif untuk Laki-Laki Pembuat Batu-Bata Tahapan Penggalian dan Pengolahan Bahan Mentah

\begin{tabular}{|c|c|c|c|c|c|c|c|c|c|}
\hline \multicolumn{2}{|c|}{ Beban Kerja } & \multicolumn{2}{|c|}{$\begin{array}{c}\text { Tahapan } \\
\text { Penggalian } \\
\text { Bahan Mentah }\end{array}$} & \multirow{2}{*}{$\begin{array}{l}\text { Median \& } \\
\text { Modus } \\
(\mathrm{Kg})\end{array}$} & \multirow{2}{*}{$\begin{array}{c}\text { Mean } \\
(\mathrm{Kg})\end{array}$} & \multicolumn{2}{|c|}{$\begin{array}{c}\text { Tahapan } \\
\text { Pengolahan } \\
\text { Bahan Mentah }\end{array}$} & \multirow{2}{*}{$\begin{array}{l}\text { Median \& } \\
\text { Modus } \\
(\mathrm{Kg})\end{array}$} & \multirow{2}{*}{$\begin{array}{c}\text { Mean } \\
(\mathrm{Kg})\end{array}$} \\
\hline Kategori & $\begin{array}{c}\text { Beban Kerja } \\
\text { Untuk Laki- } \\
\text { Laki }(\mathrm{Kg})\end{array}$ & $\mathrm{F}$ & $\%$ & & & $\mathrm{~F}$ & $\%$ & & \\
\hline 1 & $(<10)$ & - & - & & & - & - & & \\
\hline 2 & $(10-<20)$ & - & - & & & - & - & & \\
\hline 4 & $(20-<30)$ & - & - & & & - & - & & \\
\hline 7 & $(30-<40)$ & - & - & & & - & - & & \\
\hline \multirow[t]{2}{*}{25} & $(\geq 40)$ & 19 & 100 & $\begin{array}{l}\mathrm{Me}=832 \\
\mathrm{Mo}=512\end{array}$ & $1.024,84$ & 19 & 100 & $\begin{array}{l}\mathrm{Me}=800 \\
\mathrm{Mo}=736\end{array}$ & $\begin{array}{r}884,2 \\
1 \\
\end{array}$ \\
\hline & Jumlah & 19 & 100 & & & 39 & 100 & & \\
\hline
\end{tabular}

Dengan memperhatikan Tabel 6, diketahui bahwa untuk kategori beban kerja untuk laki-laki pada tahapan penggalian dan pengolahan bahan mentah dari semua responden laki-laki (100\%), beban efektif yang dibawa $\geq 40 \mathrm{~kg}$. Nilai median yang didapat yaitu $832 \mathrm{~kg}$ pada tahapan penggalian dan $800 \mathrm{~kg}$ pada tahapan pengolahan, nilai modus yang didapatkan yaitu $512 \mathrm{~kg}$ pada tahapan penggalian dan 736 pada tahapan pengolahan sehingga masuk dalam kategori 25 atau beban efektif yang dibawa $\geq 40 \mathrm{~kg}$, sedangkan rata-rata atau nilai mean beban manual handling pada laki-laki pada tahapan penggalian bahan mentah adalah $1.024,84 \mathrm{~kg} / 1$ hari kerja dan pada tahapan pengolahan bahan mentah nilai mean adalah $884,21 \mathrm{~kg} / 1$ hari kerja. Hal ini berarti seluruh responden laki-laki pada tahapan penggalian dan pengolahan bahan mentah memiliki beban yang melebihi batas yaitu $\geq 40 \mathrm{~kg} / 1$ hari kerja, dan frekuensi mengangkat beban yang berulang kali memberikan pembebanan yang berlebih kepada responden saat bekerja.

Tabel 7. Distribusi Frekuensi Beban Manual Handling Berdasarkan Beban Efektif Untuk LakiLaki Pembuat Batu-Bata pada Tahapan Pembentukan dan Pengeringan

\begin{tabular}{|c|c|c|c|c|c|c|c|c|c|}
\hline \multicolumn{2}{|c|}{ Beban Kerja } & \multicolumn{2}{|c|}{$\begin{array}{c}\text { Tahapan } \\
\text { Pembentukan } \\
\text { Batu-Bata } \\
\end{array}$} & \multirow{2}{*}{$\begin{array}{c}\text { Median \& } \\
\text { Modus (Kg) }\end{array}$} & \multirow{2}{*}{$\begin{array}{c}\text { Mean } \\
(\mathrm{Kg})\end{array}$} & \multicolumn{2}{|c|}{$\begin{array}{c}\text { Tahapan } \\
\text { Pengeringan } \\
\text { Batu-Bata } \\
\end{array}$} & \multirow{2}{*}{$\begin{array}{l}\text { Median } \\
\& \\
\text { Modus } \\
(\mathrm{Kg})\end{array}$} & \multirow{2}{*}{$\begin{array}{c}\text { Mean } \\
(\mathrm{Kg})\end{array}$} \\
\hline Kategori & $\begin{array}{c}\text { Beban Kerja } \\
\text { Untuk Laki- } \\
\text { Laki (Kg) }\end{array}$ & $\mathrm{F}$ & $\%$ & & & $\mathrm{~F}$ & $\%$ & & \\
\hline 1 & $(<10)$ & - & - & & & - & - & & \\
\hline 2 & $(10-<20)$ & - & - & & & - & - & & \\
\hline 4 & $(20-<30)$ & - & - & & & - & - & & \\
\hline 7 & $(30-<40)$ & - & - & & & - & - & & \\
\hline \multirow[t]{2}{*}{25} & $(\geq 40)$ & 19 & 100 & $\begin{array}{l}\mathrm{Me}=1.500 \\
\mathrm{Mo}=1.000\end{array}$ & $1.518,42$ & 19 & 100 & $\begin{array}{l}\mathrm{Me}=400 \\
M o=500\end{array}$ & 410,53 \\
\hline & Jumlah & 19 & 100 & & & 39 & 100 & & \\
\hline
\end{tabular}


Berdasarkan Tabel 7, diketahui untuk kategori beban kerja untuk laki-laki pada tahapan pembentukan dan pengeringan dari semua responden laki-laki (100\%), beban efektif yang dibawa $\geq 40 \mathrm{~kg}$. Nilai median yang didapat yaitu $1.500 \mathrm{~kg}$ pada tahapan pembentukan dan $400 \mathrm{~kg}$ pada tahapan pengeringan, nilai modus yang didapatkan yaitu $1.000 \mathrm{~kg}$ pada tahapan pembentukan dan $500 \mathrm{~kg}$ pada tahapan pengeringan sehingga masuk dalam kategori 25 atau beban efektif yang dibawa $\geq 40 \mathrm{~kg}$, sedangkan rata-rata atau nilai mean beban manual handling pada laki-laki pada tahapan pembentukan adalah 1.518,42 kg/ 1 hari kerja dan pada tahapan pengeringan adalah $410,53 \mathrm{~kg} /$ 1 hari kerja. Hal ini berarti seluruh responden laki-laki pada tahapan pembentukan dan pengeringan batu-bata memiliki beban yang melebihi batas yaitu $\geq 40 \mathrm{~kg} / 1$ hari kerja, dan frekuensi mengangkat beban yang berulangkali memberikan pembebanan yang berlebih kepada responden saat bekerja.

\section{b. Untuk Wanita}

Tabel 8. Distribusi Frekuensi Beban Manual Handling Berdasarkan Beban Efektif Untuk Wanita Pembuat Batu-Bata Tahapan Penggalian dan Pengolahan Bahan Mentah

\begin{tabular}{|c|c|c|c|c|c|c|c|c|c|}
\hline \multicolumn{2}{|c|}{ Beban Kerja } & \multicolumn{2}{|c|}{$\begin{array}{c}\text { Tahapan } \\
\text { Pembentukan } \\
\text { Batu-Bata }\end{array}$} & \multirow{2}{*}{$\begin{array}{c}\text { Median \& } \\
\text { Modus }(\mathrm{Kg})\end{array}$} & \multirow{2}{*}{$\begin{array}{c}\text { Mean } \\
(\mathrm{Kg})\end{array}$} & \multicolumn{2}{|c|}{$\begin{array}{c}\text { Tahapan } \\
\text { Pengeringan } \\
\text { Batu-Bata }\end{array}$} & \multirow{2}{*}{$\begin{array}{c}\text { Median } \\
\& \\
\text { Modus } \\
(\mathrm{Kg})\end{array}$} & \multirow{2}{*}{$\begin{array}{c}\text { Mean } \\
(\mathrm{Kg})\end{array}$} \\
\hline Kategori & $\begin{array}{l}\text { Beban Kerja Untuk } \\
\text { Laki-Laki }(\mathrm{Kg})\end{array}$ & $\mathrm{F}$ & $\%$ & & & $\mathrm{~F}$ & $\%$ & & \\
\hline 1 & $(<5)$ & - & - & & & - & - & & \\
\hline 2 & $(5-<10)$ & - & - & & & - & - & & \\
\hline 4 & $(10-<15)$ & - & - & & & - & - & & \\
\hline 7 & $(16-\leq 25)$ & 20 & 100 & $\begin{array}{l}\mathrm{Me}=1.400 \\
\mathrm{Mo}=1.500\end{array}$ & 1.300 & 20 & 100 & $\begin{array}{l}\mathrm{Me}=300 \\
\mathrm{Mo}=200\end{array}$ & 340 \\
\hline & Jumlah & 20 & 100 & & & 20 & 100 & & \\
\hline
\end{tabular}

Berdasarkan Tabel 8, diketahui dari semua responden wanita, beban efektif yang dibawa 16$\geq 25 \mathrm{~kg}$ pada tahapan penggalian dan pengolahan bahan mentah. Nilai median didapat $800 \mathrm{~kg}$ pada tahapan penggalian dan $400 \mathrm{~kg}$ pada tahapan pengolahan, nilai modus yaitu $800 \mathrm{~kg}$ pada tahapan penggalian dan $400 \mathrm{~kg}$ pada tahapan pengolahan sehingga masuk dalam kategori 7 atau beban efektif yang dibawa 16- $\geq 25 \mathrm{~kg}$, sedangkan nilai mean beban manual handling pada wanita tahap penggalian bahan mentah adalah $835,60 \mathrm{~kg} / 1$ hari kerja dan pada tahapan pengolahan bahan mentah 479,60 kg/ 1 hari kerja. Berarti seluruh responden wanita pada tahap penggalian dan pengolahan bahan mentah memiliki beban melebihi batas $16-\geq 25 \mathrm{~kg} / 1$ hari kerja, frekuensi mengangkat beban berulangkali memberikan pembebanan berlebih ke responden saat bekerja, kedua hal tersebut dapat menjadi faktor risiko terjadinya nyeri punggung bawah.

Tabel 9. Distribusi Frekuensi Beban Manual Handling Berdasarkan Beban Efektif Untuk Wanita Pembuat Batu-Bata pada Tahapan Pembentukan dan Pengeringan

\begin{tabular}{|c|c|c|c|c|c|c|c|c|c|}
\hline \multicolumn{2}{|r|}{ Beban Kerja } & \multicolumn{2}{|c|}{$\begin{array}{c}\text { Tahapan } \\
\text { Penggalian } \\
\text { Bahan Mentah }\end{array}$} & \multirow{2}{*}{$\begin{array}{l}\text { Median \& } \\
\text { Modus } \\
\text { (Kg) }\end{array}$} & \multirow{2}{*}{$\begin{array}{c}\text { Mean } \\
(\mathrm{Kg})\end{array}$} & \multicolumn{2}{|c|}{$\begin{array}{c}\text { Tahapan } \\
\text { Pengolahan } \\
\text { Bahan Mentah }\end{array}$} & \multirow{2}{*}{$\begin{array}{l}\text { Median \& } \\
\text { Modus } \\
\text { (Kg) }\end{array}$} & \multirow{2}{*}{$\begin{array}{c}\text { Mean } \\
(\mathrm{Kg})\end{array}$} \\
\hline Kategori & $\begin{array}{c}\text { Beban Kerja Untuk } \\
\text { Wanita }(\mathrm{Kg})\end{array}$ & $\mathrm{F}$ & $\%$ & & & $\mathrm{~F}$ & $\%$ & & \\
\hline 1 & $(<5)$ & - & - & & & - & - & & \\
\hline 2 & $(5-<10)$ & - & - & & & - & - & & \\
\hline 4 & $(10-<15)$ & - & - & & & - & - & & \\
\hline \multirow[t]{2}{*}{7} & $(16-\geq 25)$ & 20 & 100 & $\begin{array}{l}\mathrm{Me}=800 \\
\mathrm{Mo}=800\end{array}$ & 835,60 & 20 & 100 & $\begin{array}{l}\mathrm{Me}=400 \\
\mathrm{o}=400\end{array}$ & 479,60 \\
\hline & Jumlah & 20 & 100 & & & 20 & 100 & & \\
\hline
\end{tabular}

Tabel 9 menyajikan, bahwa dari semua responden wanita $(100 \%)$, beban efektif yang dibawa $16-\leq 25 \mathrm{~kg}$ pada tahapan pembentukan dan pengeringan batu-bata. Nilai median yang didapat $1.400 \mathrm{~kg}$ pada tahapan pembentukan dan $300 \mathrm{~kg}$ pada tahapan pengeringan, nilai modus dapatkan $1.500 \mathrm{~kg}$ pada tahapan pembentukan dan $200 \mathrm{~kg}$ pada tahapan pengolahan sehingga 
masuk dalam kategori 7 atau beban efektif yang dibawa 16- $\geq 25 \mathrm{~kg}$, sedangkan nilai mean beban manual handling pada wanita tahap pembentukan adalah $1.300 \mathrm{~kg} / 1$ hari kerja dan pada tahapan pengeringan nilai mean $340 \mathrm{~kg} / 1$ hari kerja. Berarti seluruh responden wanita pada tahapan pembentukan dan pengeringan memiliki beban melebihi batas $16-\geq 25 \mathrm{~kg} / 1$ hari kerja, dan frekuensi mengangkat beban berulangkali memberikan pembebanan berlebih kepada responden saat bekerja.

4. Posture Rating Manual Handling Berdasarkan Jenis Sikap Tubuh dan Postur Tubuh Pembuat Batu-Bata Pertahapan

Tabel 10. Distribusi Posture Rating (Skor) Manual Handling Terhadap Jenis Sikap Tubuh dan Postur Tubuh pada Tahapan Penggalian dan Pengolahan Bahan Mentah

\begin{tabular}{|c|c|c|c|c|c|c|}
\hline & \multicolumn{2}{|c|}{$\begin{array}{c}\text { Tahapan } \\
\text { Penggalian } \\
\text { Bahan } \\
\text { Mentah } \\
\end{array}$} & \multicolumn{3}{|c|}{$\begin{array}{c}\text { Tahapan } \\
\text { Pengolahan } \\
\text { Bahan } \\
\text { Mentah } \\
\end{array}$} & \multirow{2}{*}{$\begin{array}{l}\text { Median } \\
\& \\
\text { Modus }\end{array}$} \\
\hline $\begin{array}{l}\text { Rating } \\
\text { (Skor) }\end{array}$ & $\mathrm{F}$ & $\%$ & & $\mathrm{~F}$ & $\%$ & \\
\hline 1 & 1 & 2,6 & & 1 & 2,6 & \\
\hline 2 & 23 & 59 & 2 & 7 & 18 & 3 \\
\hline 3 & 15 & 38,4 & & 31 & 79,4 & \\
\hline 4 & - & - & & - & - & \\
\hline Jumlah & 39 & 100 & & 39 & 100 & \\
\hline
\end{tabular}

Berdasarkan Tabel 10 diketahui dari 39 responden kategori posture rating manual handling terhadap jenis sikap tubuh dan postur tubuh tahapan penggalian bahan mentah yang paling banyak sikap tubuh dan postur tubuh sedikit membungkuk ke depan atau sedikit memutirkan badan dalam melakukan pekerjaan sebanyak 23 responden (59\%), untuk tahapan pengolahan bahan mentah yang paling banyak sikap tubuh dan postur tubuh membungkuk sampai bawah atau membungkuk ke depan cukup jauh, sedikit membungkuk ke depan dengan memuntirkan badan secara simultan dalam melakukan pekerjaan sebanyak 31 responden $(79,4 \%)$. Nilai median dan modus tahapan penggalian bahan mentah yaitu 2 atau sikap tubuh dan postur tubuh sedikit membungkuk ke depan atau sedikit memutirkan badan dalam melakukan pekerjaan.
Tabel 11. Distribusi Posture Rating (Skor) Manual Handling terhadap Jenis Sikap Tubuh dan Postur Tubuh pada Tahapan Pembentukan dan Pengeringan

\begin{tabular}{|c|c|c|c|c|c|c|}
\hline \multirow{2}{*}{$\begin{array}{c} \\
\text { Posture } \\
\text { Rating } \\
\text { (Skor) }\end{array}$} & \multicolumn{2}{|c|}{$\begin{array}{c}\text { Tahapan } \\
\text { Pembentukan } \\
\text { Batu-Bata }\end{array}$} & \multirow{2}{*}{$\begin{array}{l}\text { Median } \\
\& \\
\text { Modus }\end{array}$} & \multicolumn{2}{|c|}{$\begin{array}{c}\text { Tahapan } \\
\text { Pengeringan } \\
\text { Batu-Bata }\end{array}$} & \multirow{2}{*}{$\begin{array}{l}\text { Median } \\
\& \\
\text { Modus }\end{array}$} \\
\hline & $\mathrm{F}$ & $\%$ & & $\mathrm{~F}$ & $\%$ & \\
\hline 1 & - & - & & 2 & 5,1 & \\
\hline 2 & - & - & & 9 & 23,1 & \\
\hline 3 & 34 & 87,2 & 3 & 8 & 20,5 & \\
\hline 4 & 5 & 12,8 & & 20 & 51,3 & 4 \\
\hline Jumlah & 39 & 100 & & 39 & 100 & \\
\hline
\end{tabular}

Berdasarkan Tabel 11 didapatkan pada tahapan pembentukan batu-bata yang paling banyak adalah sikap tubuh dan postur tubuh membungkuk sampai bawah atau membungkuk ke depan cukup jauh, sedikit membungkuk ke depan dengan memuntirkan badan secara simultan dalam melakukan pekerjaan sebanyak 34 responden $(87,2 \%)$. Serta pada tahapan pengeringan batu-bata yang paling banyak adalah sikap tubuh dan postur tubuh membungkuk jauh ke depan dengan memuntirkan badan secara simultan, stabilitas tubuh terbatas saat berdiri, jongkok dan atau berlutut dalam melakukan pekerjaan sebanyak 20 responden $(51,3 \%)$. Nilai median dan modus pada pembentukan batu-bata yaitu 3, sedangkan pada tahapan pengeringan batu-bata nilai median dan modusnya yaitu 4 .

\section{Kondisi Kerja Manual Handling Pembuat Batu-Bata Pertahapan}

Tabel 12. Distribusi Rating (Skor) Kondisi Kerja Manual Handling pada Tahapan Penggalian dan Pengolahan Bahan Mentah

\begin{tabular}{|c|c|c|c|c|c|c|}
\hline & \multicolumn{2}{|c|}{$\begin{array}{c}\text { Tahapan } \\
\text { Penggalian } \\
\text { Bahan } \\
\text { Mentah }\end{array}$} & \multicolumn{4}{|c|}{$\begin{array}{c}\text { Tahapan } \\
\text { Pengolahan }\end{array}$} \\
\hline $\begin{array}{l}\text { (Skor) } \\
\text { Kondisi } \\
\text { Kerja }\end{array}$ & $\mathrm{F}$ & $\%$ & Nivous & $\mathrm{F}$ & $\%$ & IVIoutus \\
\hline 0 & 5 & 12,8 & & 3 & 7,7 & \\
\hline 1 & 23 & 59 & 1 & 22 & 56,4 & 1 \\
\hline 2 & 11 & 28,2 & & 14 & 35,9 & \\
\hline Jumlah & 39 & 100 & & 39 & 100 & \\
\hline
\end{tabular}

Berdasarkan hasil Tabel 12 dapat diketahui bahwa dari 39 responden untuk kategori kondisi kerja manual handling pada tahapan penggalian bahan mentah yang paling banyak adalah melakukan pekerjaan di kondisi yang ruang 
untuk bergerak dan keadaan lantai tidak rata sebanyak 23 responden (59\%). Untuk tahapan pengolahan bahan mentah yang paling banyak adalah \%) melakukan pekerjaan di kondisi yang terbatas ruang untuk bergerak dan keadaan lantai tidak rata sebanyak 22 responden $(56,4 \%)$. Nilai median dan modus dikedua tahapan yaitu 1 atau melakukan pekerjaan di kondisi yang ruang untuk bergerak dan keadaan lantai tidak rata.

Tabel 13. Distribusi Rating (Skor) Kondisi Kerja Manual Handling pada Tahapan Pembentukan dan Pengeringan

\begin{tabular}{|c|c|c|c|c|c|c|}
\hline & \multicolumn{2}{|c|}{$\begin{array}{c}\text { Tahapan } \\
\text { Pembentu } \\
\text { kan Batu- } \\
\text { Bata } \\
\end{array}$} & \multirow{2}{*}{$\begin{array}{l}\text { Median } \\
\& \\
\text { Modus }\end{array}$} & \multicolumn{2}{|c|}{$\begin{array}{c}\text { Tahapan } \\
\text { Pengeringan } \\
\text { Batu-Bata }\end{array}$} & \multirow{2}{*}{$\begin{array}{l}\text { Median } \\
\& \\
\text { Modus }\end{array}$} \\
\hline $\begin{array}{l}\text { (Skor) } \\
\text { Kondisi } \\
\text { Kerja }\end{array}$ & F & $\%$ & & $\mathrm{~F}$ & $\%$ & \\
\hline 0 & 33 & 84,6 & 0 & 30 & 76,9 & 0 \\
\hline 1 & 6 & 15,4 & & 4 & 10,2 & \\
\hline 2 & - & - & & 5 & 12,8 & \\
\hline Jumlah & 39 & 100 & & 39 & 100 & \\
\hline
\end{tabular}

Berdasarkan hasil Tabel 13 pada tahapan pembentukan batu-bata yang paling banyak adalah melakukan pekerjaan di kondisi yang kondisi ergonomi yang baik, tidak ada yang menghalangi beban kerja dan pencahayaan bagus sebanyak 33 responden $(84,6 \%)$. Serta pada tahapan pengeringan batu-bata yang paling banyak adalah melakukan pekerjaan di kondisi yang kondisi ergonomi yang baik, tidak ada yang menghalangi beban kerja dan pencahayaan bagus sebanyak 30 responden $(76,9 \%)$. Nilai median dan modus dikedua tahapan tersebuta yaitu 0 atau melakukan pekerjaan di kondisi ergonomi baik, tidak ada yang menghalangi beban kerja dan pencahayaan bagus.

\section{Keluhan Subjektif Nyeri Punggung Bawah}

Tabel 14. Distribusi Responden Berdasarkan Keluhan Subjektif Nyeri Punggung Bawah

\begin{tabular}{lrr}
\hline $\begin{array}{c}\text { Nyeri Punggung } \\
\text { Bawah }\end{array}$ & Frekuensi & \multicolumn{1}{c}{$\%$} \\
\hline Akut $(0-10)$ & 26 & 66,7 \\
Kronis $(11-20)$ & 13 & 33,3 \\
\hline Jumlah & 39 & 100 \\
\hline
\end{tabular}

Berdasarkan hasil Tabel 14 dapat diketahui bahwa dari 39 responden yang diperoleh terdapat 26 orang $(66,7 \%)$ yang mengalami keluhan nyeri punggung bawah akut sedangkan 13 orang
$(33,3 \%)$ lainnya mengalami keluhan nyeri punggung bawah kronis.

\section{PEMBAHASAN}

Hubungan Waktu Manual Handling dengan Keluhan Nyeri Punggung Bawah pada Semua Tahapan Pembuatan Batu-bata

Berdasarkan hasil penelitian diketahui pada 3 tahapan pembuatan batu-bata yaitu tahapan penggalian bahan mentah, pembentukan batu-bata dan pengeringan batu-bata didapatkan adanya hubungan antara waktu manual handling berdasarkan frekuensi (jumlah/ 1 hari kerja) mengangkat atau operasi pemindahan $(<5$ detik) dengan keluhan nyeri punggung bawah karena hasil penelitian menunjukkan $p$ value pada tahapan penggalian bahan mentah sebesar 0,039 $(\leq 0,05)$, tahapan pembentukan batu-bata 0,047 $(\leq 0,05)$, dan tahapan pengeringan hasil penelitian menunjukkan $p$ value sebesar $0,038(\leq 0,05)$.

Sedang tahap pengolahan bahan mentah hasil penelitian $\mathrm{p}$ value sebesar $0,545(>0,05)$ sehingga tidak ada hubungan antara waktu manual handling berdasarkan frekuensi (jumlah/ 1 hari kerja) mengangkat atau operasi pemindahan ( $<5$ detik) dengan keluhan nyeri punggung bawah pada pembuat batu-bata.

Hasil ini diperkuat penelitian (Santiasih, 2013), bahwa indek pengangkatan berhubungan dengan keluhan nyeri punggung bawah pada pekerja tekstil. Kegiatan mengangkat atau operasi pemindahan dalam pembuatan batu-bata termasuk kedalam gerakan berulang, dapat dikatakan seperti itu karena dalam sekali tahapan terdapat gerakan yang dilakukan berulangkali, misal di tahapan penggalian bahan mentah, gerakan menggali tanah dengan cangkul. Pengulangan gerakan kerja dengan pola yang sama terlampau sering akan mendorong fatigue dan ketegangan otot tendon. Dampak gerakan berulang akan meningkat bila gerakan tersebut dilakukan dengan postur janggal dengan beban yang berat dalam waktu yang lama. Frekuensi terjadinya sikap tubuh terkait dengan berapa kali repetitive motion dalam melakukan pekerjaan. Keluhan otot terjadi karena otot menerima tekanan akibat beban terus menerus tanpa memperoleh kesempatan untuk relaksasi.

Menurut (Mayrika dalam Saputro, 2016) pekerja yang mengangkat dan membawa beban setiap hari, maka tulang belakangnya akan terus mengalami penekanan sehingga lama kelamaan sikap tubuhnya berubah. Perubahan terjadi sebagai akibat dari kebiasaan bertumpu saat 
membawa beban, cara bekerja didalam waktu lama dengan sikap yang salah (tidak ergonomi), dapat menyebabkan low back pain kronis.

Upaya pengendalian keluhan nyeri punggung bawah terkait waktu manual handling berdasarkan frekuensi (jumlah/ 1 hari kerja) pengangkatan atau operasi pemindahan yang dapat dilakukan pada setiap tahapan pembuatan batu-bata yaitu pada tahapan penggalian bahan mentah dapat dilakukan dengan menggunakan cangkul yang ringan sehingga saat mengangkat beban bahan mentah tanah liat dengan frekuensi yang banyak tidak begitu berat, serta mengurangi frekuensi pengangkatan atau operasi pemindahan. Pada tahapan pengolahan bahan mentah dapat dilakukan dengan penggunaan cangkul yang terbuat dari bahan yang ringan, serta mengurangi frekuensi pengangkatan atau operasi pemindahan. Pada tahapan pembentukan batu-bata dapat dilakukan dengan penggunaan ember untuk wadah adonan bahan mentah yang terbuat dari bahan yang ringan sehingga beban yang dibawa tidak terlalu berat walaupun dengan frekuensi pengangkatan atau operasi pemindahan yang banyak.

\section{Hubungan antara Beban Manual Handling dengan Keluhan Nyeri Punggung Bawah}

\section{a. Untuk Laki-Laki}

Berdasarkan hasil penelitian pada semua tahapan pembuatan batu-bata didapatkan tidak adanya hubungan antara beban manual handling berdasarkan beban efektif untuk laki-laki dengan keluhan nyeri punggung bawah. Hal ini dikarenakan hasil penelitian $p$ value di semua tahapan pembuatan batu-bata tidak terbaca. Hasil penelitian ini tidak sejalan dengan penelitian (Nurzannah, 2015) yang menyatakan bahwa ada hubungan antara beban kerja dengan keluhan nyeri punggung bawah, namun pada penelitian ini lebih spesifik pada beban kerja manual handling dan pada setiap tahapan pembuatan batu-bata. Hal ini dapat disebabkan karena semua responden laki-laki pada semua tahapan pembuatan batu-bata memiliki beban kerja yang melebihi $\geq 40 \mathrm{~kg}$ yang mana sesuai dengan checklist menurut (Tarwaka, 2015) sehingga tidak terdapat variasi dalam penelitian ini.

Beratnya beban yang diangkat oleh tenaga kerja yang semuanya $\geq 40 \mathrm{Kg}$ untuk sekali angkat memberikan pembebanan yang berlebih. Jika beban yang diangkat tidak mampu ditopang oleh tubuh, maka dapat menyebabkan terjadinya cedera misalnya saja pada tulang belakang yang mengalami nyeri baik itu punggung belakang, bahu maupun punggung bagian atas. Akibat dari beban yang terlalu berat atau kemampuan fisik yang terlalu lemah dapat mengakibatkan seorang pekerja menderita gangguan atau penyakit akibat kerja. Menurut Peraturan Menteri Tenaga Kerja, Transmigrasi dan Koperasi No Per.01/MEN 1978 tentang Keselamatan dan Kesehatan Kerja bahwa berat beban maksimal untuk tenaga kerja pria dewasa yang sekali-kali mengangkat adalah $40 \mathrm{~kg}$ (Nurwahyuni, 2012).

Upaya pengendalian keluhan nyeri punggung bawah terkait beban manual handling untuk laki-laki yang dapat dilakukan pada setiap tahapan pembuatan batu-bata yaitu pada tahapan penggalian bahan mentah dapat dilakukan dengan menggunakan cangkul yang ringan, diselingi istirahat minimal 1 kali istirahat dalam 8 jam kerja/hari. Pada tahapan pengolahan bahan mentah dapat dilakukan dengan penggunaan cangkul yang terbuat dari bahan yang ringan, serta diselingi istirahat minimal 1 kali istirahat dalam 8 jam kerja/hari.

\section{b. Untuk Wanita}

Berdasarkan hasil penelitian pada semua tahapan pembuatan batu-bata didapatkan tidak adanya hubungan antara beban manual handling berdasarkan beban efektif untuk wanita dengan keluhan nyeri punggung bawah. Hal ini dikarenakan hasil penelitian $p$ value disemua tahapan pembuatan batu-bata tidak terbaca. Hal ini dapat disebabkan karena semua responden wanita pada semua tahapan pembuatan batu-bata memiliki beban kerja yang melibihi $\geq 25 \mathrm{~kg}$ sehingga tidak terdapat variasi dalam penelitian ini. Hal ini sejalan penelitian (Pratiwi, 2009) bahwa beban kerja tidak berhubungan dengan nyeri punggung bawah.

Hasil penelitian menunjukkan 100\% pembuat batu-bata wanita mengangkat beban yang beratnya $>25 \mathrm{~kg}$. Semakin berat beban yang diangkat, tulang belakang akan bekerja semakin keras untuk menahan beban tersebut. Pembebanan berlebihan pada tulang belakang mengakibatkan tulang belakang menjadi rusak sampai terjadi Hernia Nukleus Pulposus yang merupakan salah satu faktor terjadinya nyeri punggung bawah. Oleh karena itu, semakin berat beban yang diangkat, maka kemungkinan terpapar nyeri punggung bawah juga semakin besar (Nurmianto dalam Pratiwi, 2009).

Upaya pengendalian keluhan nyeri punggung bawah terkait beban manual handling untuk wanita yang dapat dilakukan pada setiap tahapan pembuatan batu-bata yaitu pada tahapan penggalian bahan mentah dapat dilakukan dengan menggunakan cangkul yang ringan, diselingi 
istirahat minimal 1 kali istirahat dalam 8 jam kerja/hari. Pada tahapan pengolahan bahan mentah dapat dilakukan dengan penggunaan cangkul yang terbuat dari bahan yang ringan, serta diselingi istirahat minimal 1 kali istirahat dalam 8 jam kerja/hari. Pada tahapan pembentukan batu-bata dapat dilakukan dengan penggunaan ember untuk wadah adonan bahan mentah yang terbuat dari bahan yang ringan sehingga beban yang dibawa tidak terlalu berat.

\section{Hubungan antara Sikap Tubuh Manual Handling dengan Keluhan Nyeri Punggung Bawah}

Berdasarkan hasil penelitian ini dari 39 responden pembuat batu-bata pada semua tahapan pembuatan batu-bata, didapatkan tidak adanya hubungan antara posture rating (skor) manual handling terhadap jenis sikap tubuh dan postur tubuh dengan keluhan nyeri punggung bawah dikarenakan hasil nilai $p$ value disemua tahapan pembuatan batu-bata melebihi atau lebih besar dari 0,05. Hal ini tidak sejalan dengan penelitian (Sakinah, 2012), bahwa ada hubungan antara sikap tubuh dengan keluhan nyeri punggung bawah pada pekerja batu bata di Kelurahan Lawawoi Kabupaten Sidrap.

Hal tersebut menunjukkan bahwa sikap kerja tenaga kerja pada saat melakukan pekerjaan manual handling disemua tahapan pembuatan batu-bata sudah termasuk kategori yang benar. Masa kerja yang rata-rata $>5$ tahun memberikan mereka pengalaman untuk menciptakan cara melakukan pekerjaan manual handling secara alamiah yang membuat bisa lebih nyaman dan tidak menimbulkan masalah bagi mereka.

Posisi kerja yang statis juga merupakan penyebab nyeri punggung bawah. Sikap kerja statis dalam jangka waktu lama lebih cepat menimbulkan keluhan pada system musculoskeletal. Apabila dibiarkan terus-menerus dan tidak memperhatikan faktor-faktor ergonomi akan lebih mudah menimbulkan keluhan nyeri punggung bawah (Sakinah, 2012).

Nyeri punggung bawah disebabkan adanya penekanan pada susunan saraf tepi didaerah pinggang atau dengan kata lain sarafnya berada pada posisi terjepit, sehingga otot mengalami spasme. Spasme yang terjadi karena gerakan pinggang yang terlalu mendadak atau berlebihan melampaui kekuatan otot tersebut. Saat mengangkat beban berat dan dalam frekuensi yang lama otot di sekitar lumbosakral memberikan beban yang berat sehingga jika sudah melampaui dari kekuatan otot inilah yang menyebabkan nyeri (Smeltzer \& Bare dalam Rinaldi, 2015). Hal tersebut terjadi karena postur tubuh yang tidak ergonomis. Kegiatan berulang merupakan salah satu penyebab terjadinya keluhan musculoskeletal.

Upaya pengendalian keluhan nyeri punggung bawah terkait postur dan sikap tubuh manual handling yang dapat dilakukan pada setiap tahapan pembuatan batu-bata yaitu pada tahapan penggalian bahan mentah dapat dilakukan dengan memperhatikan sikap tubuh yang benar saat menggali tanah liat, diselingi istirahat minimal 1 kali istirahat dalam 8 jam kerja/hari. Pada tahapan pengolahan bahan mentah dapat dilakukan dengan memperhatikan postur dan sikap tubuh yang benar saat mencangkul tanah, serta diselingi istirahat minimal 1 kali istirahat dalam 8 jam kerja/hari. Pada tahapan pembentukan batu-bata dapat dilakukan dengan memperhatikan postur dan sikap tubuh yang benar saat pembentukan batubata seperti saat jongkok dan mengangkat beban.

\section{Hubungan Kondisi Kerja Manual Handling dengan Keluhan Nyeri Punggung Bawah}

Berdasarkan penelitian, didapatkan bahwa pada tahapan penggalian bahan mentah terdapat hubungan antara kondisi kerja manual handling dengan keluhan nyeri punggung bawah dengan hasil $p$ value sebesar $0,028(\leq 0,05)$, sedangkan tahapan pengolahan bahan mentah, pembentukan dan pengeringan batu-bata semua tidak terdapat hubungan antara kondisi kerja manual handling dengan keluhan nyeri punggung bawah.

Rahayu (2012) menyatakan kondisi kerja pemecahan batu di Kecamatan Karangnongko Kabupaten Klaten yaitu kondisi ergonomi baik, terdapat cukup ruang untuk bekerja dan kondisi pencahayaan bagus sehingga didapatkan final rating tingkat 3 yaitu situasi beban kerja meningkat tinggi dan pembebanan fisik berlebih mungkin dialami oleh pekerja normal, namun dalam penelitian ini tidak sampai dengan penilaian final rating hanya menghubungkan anatara kondisi kerja manual handling dengan keluhan nyeri punggung bawah.

Upaya pengendalian keluhan nyeri punggung bawah terkait kondisi kerja manual handling yaitu, tahapan penggalian bahan mentah dilakukan dengan memperhatikan lantai karena lantai tidak rata, sikap tubuh yang benar dan nyaman agar tidak terpeleset maupun jatuh, diselingi istirahat minimal 1 kali istirahat dalam 8 jam kerja/hari. Tahap pengolahan bahan mentah dapat dilakukan dengan memperhatikan lantai karena lantai licin, memperhatikan sikap tubuh yang benar dan nyaman agar tidak terpeleset maupun jatuh, diselingi istirahat minimal 1 kali 
istirahat dalam 8 jam kerja/ hari. Pada tahapan pembentukan batu-bata dapat dilakukan dengan memperhatikan postur dan sikap tubuh yang benar saat pembentukan batu-bata seperti saat jongkok dan mengangkat beban agar tidak jatuh.

\section{SIMPULAN}

1. Ada hubungan antara waktu manual handling berdasarkan frekuensi (jumlah/ 1 hari kerja) mengangkat atau operasi pemindahan $(<5$ detik) dengan keluhan nyeri punggung bawah pada tahapan penggalian bahan mentah, pembentukan dan pengeringan. Sedangkan pada tahapan pengolahan bahan mentah tidak terdapat hubungan.

2. Tidak ada hubungan antara beban manual handling berdasarkan beban efektif untuk laki-laki dan wanita dengan keluhan nyeri punggung bawah di semua tahapan.

\section{DAFTAR PUSTAKA}

Astuti, R. D. 2009. Analisa Pengaruh Aktivitas Kerja dan Beban Angkat terhadap Kelelahan Muskuloskeletal. Gema Teknik Majalah Ilmiah Teknik, 10 (2), pp-27.

Pratiwi, Mayrika H., Yuliani Setyaningsih., Bina Kurniawan., Martini Martini. 2009. Beberapa Faktor yang Berpengaruh Terhadap Keluhan Nyeri Punggung Bawah pada Penjual Jamu Gendong. Jurnal Kesehatan Promosi Indonesia, 4(1), 61-67.

Nurwahyuni, Rafael Djajakusli, Furqaan Naiem. 2012. Faktor yang Berhubungan dengan Keluhan Nyeri Punggung Bawah pada Pekerja Bongkar Muat Barang Pelabuhan Nusantara Kota Pare-Pare Tahun 2012. Repository Universitas Hasanuddin. http://repository.unhas.ac.id/bitstream/han dle/123456789/4780/Nurwahyuni_K11108 845.pdf? sequence $=1$.

Nurzannah. 2015. Hubungan Faktor Resiko dengan Terjadinya Nyeri Punggung Bawah (Low Back Pain) pada Tenaga Kerja Bongkar Muat (TKBM) di Pelabuhan Belawan Medan Tahun 2015. Skrispsi. Ilmu Kesehatan Masyarakat. Universitas Sumatera Utara

http://repository.usu.ac.id/handle/1234567 89/48680.

Rahayu, W. A. 2012. Faktor-Faktor yang Berhubungan dengan Keluhan Muskuloskeletal pada Pekerja AngkatAngkut Industri Pemecahan Batu di Kec.
3. Tidak ada hubungan antara posture rating (skor) manual handling terhadap jenis sikap tubuh dan postur tubuh dengan keluhan nyeri punggung bawah disemua tahapan.

4. Ada hubungan antara kondisi kerja manual handling dengan keluhan nyeri punggung bawah pada tahapan penggalian bahan mentah, sedangkan pada tahapan pengolahan bahan mentah, pembentukan dan pengeringan, tidak ada hubungan antara kondisi kerja manual handling dengan keluhan nyeri punggung bawah.

\section{SARAN}

Pekerja diharapkan mampu mengenali nyeri punggung bawah lebih awal dan melakukan pengendalian keluhan nyeri punggung bawah terkait kondisi kerja (jenis kegiatan dan lamanya kerja).

Karangnongko Kabupaten Klaten. Jurnal Kesehatan Masyarakat, 1(2).

Rinaldi, E. 2015. Hubungan Posisi Kerja Pada Pekerja Industri Batu Bata dengan Kejadian Low Back Pain. JOM, 2(2), 1-10. http://doi.org/10.1002/bies.201400125.

Sakinah, Rafael Djajakusli, Furqaan Naiem. 2012. Faktor yang Berhubungan dengan Keluhan Nyeri Punggung Bawah pada Pekerja Batu Bata di Kelurahan Lawawoi Kabupaten Sidrap. Repository Universitas Hasanuddin.

http://repository.unhas.ac.id/handle/12345 6789/6701.

Samara, D. 2005. Duduk Statis Sebagai Faktor Risiko Terjadinya Nyeri Punggung Bawah pada Pekerja Perempuan. Universa Medicina, 24(2), 73-79.

Santiasih, I. 2013. Kajian Manual Material Handling Terhadap Kejadian Low Back Pain Pada Pekerja Tekstil.J@ TI UNDIP: Jurnal Teknik Industri, 8(1), 21-26.

Simanjuntak, R. A. 2011. Penilaian Resiko Manual Handling dengan Metode Indikator Kunci dan Penentuan Klasifikasi Beban Kerja dengan Penentuan Cardiovasculair Load, Proceeding Seminar Nasional "Industrial Services", 8187.

Tarwaka. 2015. Dasar-Dasar Pengetahuan Ergonomi dan Aplikasi di Tempat Kerja. Solo: Harapan Press Solo. 

